Кулева Л.О.

KАTЕТОРИЯ НЕОСТОРОЖНЫХ ТЯХКИХ ПРЕСТУПЛЕНИЙ НУХДАЕТСЯ В РЕФОРМИРОВАНИИ 1

\title{
Kuleva L.O. CATEGORY OF CARELESSSERIOUS CRIMES NEEDS REFORM
}

\begin{abstract}
В работе анализу подвергаются изменения ст. 15 УК РФ в части возвращения в уголовный закон в июне 2019 года неосторожных тяжких преступлений. Автор полагает, что подход к определению наказуемости за неосторожные тяжкие преступления должен быть изменен за счет установления в ст. 15 УК РФ одних и тех же пределов наказуемости умышленных и неосторожных преступлений, поскольку основание категоризации преступлений должно быть единым. Отмечается, что УК РФ содержит составы неосторожных преступлений средней тяжести, за которые предусмотрены большие размеры наказаний, а их совершение вызывает общественный резонанс, что свидетельствует о высоком уровне общественной опасности. Такие деяния нуждаются в переводе в категорию тяжких преступлений.
\end{abstract}

Ключевые слова: неосторожные преступления, преступления средней тяжести, тяжкие преступления, уровень общественной опасности, наказание.

The article analyzes changes in art. 15 of the Criminal Code of the Russian Federation regarding the return to the criminal law in June 2019 of careless serious crimes. The author believes that the approach to determining punishability for careless serious crimes should be changed by establishing in art. 15 of the Criminal Code of the Russian Federation, the same limits of punishment for intentional and careless crimes, since the basis for the categorization of crimes should be the same. It is noted that the Criminal Code of the Russian Federation contains elements of careless crimes of average gravity, for which large amounts of punishment are provided, and their commission causes a public outcry, which indicates a high level of public danger. Such acts need to be transferred to the category of serious crimes.

Keywords: careless crimes, medium gravity crimes, serious crimes, the level of public danger, punishment.

Общеизвестно, что уголовный закон претерпевает постоянные изменения, причем модификациям подвергаются не только положения Особенной части, но также и базовые нормы - статьи Общей части УК РФ, исключением не является и ст.15. В самой первой ее редакции наказуемость преступлений тех или иных категорий не зависела от формы вины, при этом преступлениями небольшой, средней тяжести и тяжкими преступлениями признавались как умышленные, так и неосторожные деяния. Спустя несколько лет Федеральный закон от 09 марта 2001 года № 25-Ф3 внес изменения в ст. 15 УК
РФ, установив дифференцированные размеры наказуемости в ч. 3 в зависимости от формы вины. Так, преступлениями средней тяжести стали признаваться умышленные деяния, за совершение которых было предусмотрено максимальное наказание в виде пяти лет лишения свободы, а также неосторожные деяния, максимальное наказание за совершение которых превышало два года лишения свободы. При этом неосторожные тяжкие преступления были исключены из уголовного закона.

В последующем Федеральным законом от 07 декабря 2011 года № 420-Ф3 в

${ }_{1}^{1}$ Выполнение исследования в рамках государственного задания на НИР Яргу. 
ст. 15 УК РФ минимальная граница неосторожных деяний средней тяжести была изменена с двух на три года лишения свободы, соответственно за счет этого в законе искусственно увеличилось количество преступлений небольшой тяжести. Последние изменения в ст. 15 УК РФ были внесены Федеральным законом от 17 июня 2019 года № 146-Ф3, который скорректировал размеры наказуемости за совершение неосторожных преступлений средней тяжести (наказание за их совершение не превышает десяти лет лишения свободы), а также вернулся к выделению неосторожных тяжких преступлений (наказание за их совершение не превышает пятнадцати лет лишения свободы). Внесение этих изменений было следствием усиления ответственности за транспортные преступления со смертельным исходом (ст. 263, 264 УК РФ).В пояснительной записке обозначалось следующее: «Задачу по снижению уровня смертности в результате дорожно-транспортных происшествий предлагается реализовать посредством ужесточения ответственности водителей за нарушение правил дорожного движения» 1.

Мы разделяем позицию об ограничении рамок наказуемости за неосторожные преступления средней тяжести и стое убийство (ч. 1 ст. 105 УК РФ). Кроме того, выделение отдельной группы тяжких неосторожных преступлений в такой редакции неоправданно, поскольку к ней относится всего лишь четыре состава преступлений, за два из которых установлено наказание в виде лишения свободы на срок от пяти до двенадцати лет (ч. 21 ст. 263, ч. 4 ст. 264 УК РФ), за два других - на срок от восьми до пятнадцати лет (ч. 4 ст. 263, ч. 6 ст. 264 УК РФ). В этой связи в официальном отзыве Правительства РФ совершенно справедливо было указано, что «увеличение санкций, предусмотренных только двумя статьями Особенной части Кодекса, не может рассматриваться в качестве достаточного основания для корректировки положений его Общей части»².

Проанализировав размеры наказаний, предусмотренных за совершение неосторожных преступлений средней тяжести, следует сказать, что в большинстве случаев максимальное наказание в виде лишения свободы равняется пяти годам. Вместе с тем в УК РФ имеется двадцать один состав неосторожных преступлений средней тяжести, максимум типового наказания за совершение которых равняется семи, восьми, десяти годам лишения свободы (см. табл. 1).

Таблица 1

\begin{tabular}{|c|c|}
\hline Статья УК РФ & $\begin{array}{l}\text { Наказание в виде } \\
\text { лишения свободы }\end{array}$ \\
\hline $\begin{array}{l}\text { ч. } 3 \text { ст. } 215, \text { ч. } 3 \text { ст. } 216, \text { ч. } 3 \text { ст. } 217, \text { ч. } 3 \text { ст. } 2171 \text {, ч. } 3 \text { ст. } \\
219, \text { ч. } 3 \text { ст. } 263 \text {, ч. } 3 \text { ст. } 2631, \text { ч. } 5 \text { ст. } 264, \text { ч. } 3 \text { ст. } 266, \text { ч. } 3 \\
\text { ст. } 268, \text { ч. } 2 \text { ст. } 2711, \text { ч. } 3 \text { ст. } 350 \text {, ст. } 351 \text {, ст. } 352\end{array}$ & до семи лет \\
\hline ч. 3 ст. 236 & от пяти до семи лет \\
\hline ч. 12 ст. 263, ч. 2 ст. 264 & от трех до семи лет \\
\hline ч. 4 ст. 2631 & от пяти до восьми лет \\
\hline ч. 5ст. 267 & до восьми лет \\
\hline ч. 6 ст. 267, ч. 3 ст. 349 & до десяти лет \\
\hline
\end{tabular}

ужесточения уголовной политики в отношении деяний, влекущих человеческие жертвы. Тем не менее полагаем, что установление высоких размеров наказаний за неосторожные преступления не соответствует принципу справедливости, поскольку санкции ч. 4 ст. 263, ч. 6 ст. 264 УК РФ, предусматривающие лишение свободы на срок от восьми до пятнадцати лет, являются более суровыми в части минимального порога, чем санкция за про-

1 Пояснительная записка к проекту федерального закона № 685843-7 «О внесении изменений в Уголовный кодекс Российской Федерации» // СПС «Консультант Плюс».
Обязательным признаком всех этих составов выступают чаще всего последствия в виде смерти человека или двух и более лиц.

С учетом того, что материальным критерием категоризации преступлений является общественная опасность, то форма вины, как один из показателей общественной опасности, не может выступать дополнительным критерием деления

2 Официальный отзыв Правительства Российской Федерации от 09 апреля 2019 г. № 3040п-П4 на проект федерального закона «О внесении изменений в Уголовный кодекс Российской Федерации»// СПС «Консультант Плюс». 
преступлений на группы[1, с. 76]. В связи с этим полагаем, что преступления средней тяжести - и умышленные, и неосторожные - должны предусматривать максимальное наказание в виде пяти лет лишения свободы, а за неосторожные тяжкие преступления следует предусматривать такие же границы наказуемости, как и за умышленные тяжкие преступные деяния. Данное предложение имеет и криминологическое обоснование, поскольку с каждым годом количество преступлений, совершенных по неосторожности и повлекших многочисленные жертвы, возрастает.

Так, по факту авиакатастрофы, в которой 7 сентября 2011 года погибла ярославская хоккейная команда «Локомотив», в отношении заместителя генерального директора авиакомпании «як Сервис» было возбуждено уголовное дело, а впоследствии он был признан виновным в нарушении правил безопасности движения и эксплуатации воздушного транспорта, повлекших по неосторожности смерть сорока четырех человек (ч. 3 ст. 263 УК РФ) ${ }^{3}$. В то же время сегодня это деяние является неосторожным преступлением средней тяжести (максимум лишения свободы - семь лет), что не отвечает принципу справедливости, данная категория не отражает повышенный уровень общественной опасности такого деяния.

В 2014 году был вынесен приговор по делу об аварии в московском метро, когда произошло крушение электропоезда по причине неправильного монтажа стрелки в месте съезда на вновь строящуюся линию метро, в результате которого погибло двадцать четыре человека (ч. 3 ст. 2631 УК РФ) ${ }^{4}$. В 2015 году произошло крушение траулера «Дальний Восток», в результате которого погибло шестьдесят девять человек, руководители ООО «Магеллан», бывший капитан траулера были признаны виновными в нарушении правил безопасности мореплавания (ч. 3 ст. 263 УК РФ) ${ }^{5}$. В 2016 году в Ханты-Мансийском автономном округе произошло ДТП, в результате которого погибло двенад-

3 См.: Катастрофа пассажирского самолета Як42 в Ярославской области. Официальный сайт агентства «РИА Новости» // URL: https://ria.ru/ spravka/20160907/1476173284.html (дата обращения: 05.06.2021).

4 См.: Крушение на стрелке. Официальный сайт Российской газеты // URL: https:// rg.ru/2015/11/09/prigovor-site.html (дата обращения: 05.06.2021)

5 См.: Дело о крушении траулера «Дальний Восток». Официальный сайт ИA «Regnum» // URL: https://regnum.ru/news/society/2347050.html (дата обращения: 05.06.2021). цать человек, среди которых было десять детей акробатов, спустя два года был вынесен приговор в отношении водителя автобуса (ч. 5 ст. 264 УК РФ) .

В 2017 году водитель лесовоза врезался в микроавтобус, что повлекло гибель пятнадцати человек, водитель и арендатор лесовоза были признаны виновными в совершении преступлений, предусмотренных ч. 5 ст. 264 УК РФ и ч. 4 ст. 2631 УК РФ соответственно ${ }^{7}$. В 2018 году Московским межрегиональным следственным управлением на транспорте СК РФ было возбуждено уголовное дело по факту гибели семидесяти одного человека в результате крушения пассажирского самолета 11 февраля 2018 года ${ }^{8}$.

Резонансное ДТП произошло 8 июня 2020 года, когда актер Михаил Ефремов, находясь в состоянии алкогольного опьянения, управляя автомобилем, выехал на встречную полосу и столкнулся с другим автомобилем, водитель которого впоследствии скончался. Ефремов был признан виновным в совершении преступления, предусмотренного п. «а» 4. 4 ст. 264 УК РФ ${ }^{9}$

В 2021 году водителю микроавтобуса, который вез воспитанниц спортивной школы олимпийского резерва на соревнования из Волгограда в Черкесск, было предъявлено обвинение в совершении ДТП, повлекшего гибель пяти человек (ч. 5 ст. 264 УК РФ) $)^{10}$.

Очевидно, что данные деяния не только из-за наказуемости свыше пяти лет, но и в силу их особого характера должны относиться к тяжким. Критерий деления для умышленных и неосторожных преступле-

6 См.:После гибели детей в дтП в ХМАО задержали директора спортшколы. Официальный сайт РБК // URL: http://www.rbc.ru/society/06/12/2016 /5846a6659a794747a2a36e8a (дата обращения: 05.06.2021).

${ }^{7}$ См.: Приговор по делу о гибели детей в Югре. Официальный сайт ИА «Regnum» // URL: https:// regnum.ru/news/society/2381881.html (дата обращения: 05.06.2021).

8 См.: СК возбудил дело после крушения пассажирского самолета АН-148 в Подмосковье. Официальный сайт Российского агентства правовой и судебной информации // URL: http://rapsinews. ru/incident_news/20180211/281905634.html (дата обращения: 05.06.2021)

${ }^{9}$ См.: Приговор Михаилу Ефремова. Официальный сайт «Российской газеты» // URL: https:// rg.ru/2020/09/08/sud-prigovoril-aktera-mihailaefremova-k-8-godam-kolonii-obshchego-rezhima. html (дата обращения: 05.06.2021).

${ }^{10}$ См.: Предъявлено обвинение по делу о гибели пяти волгоградских спортсменок. Официальный сайт газеты «Коммерсантъ» // URL: https://www. kommersant.ru/doc/4827853 (дата обращения: 05.06.2021). 
ний должен быть единым, ибо цена преступности единая, а наносимый ущерб аналогичный. Масштабы указанных трагедий очевидны, а уголовно-правовые последствия не соответствуют данному деянию, они должны быть более суровыми. Перевод данных деяний в категорию тяжких преступлений повлечет за собой усиление уголовно-правовых последствий: невозможность освобождения от ответственности по ст. 75, 76, 762 УК РФ, увеличение сроков давности, судимости, сроков, по истечение которых лицо может быть условно-досрочно освобождено от наказания, и др.

Таким образом, уместным представляется существование в УК РФ категории тяжких преступлений (как умышленных, так и неосторожных), за совершение которых следует предусмотреть наказание в виде лишения свободы на срок от пяти до десяти лет. При этом многие престу- пления средней тяжести, совершаемые с неосторожной формой вины, необходимо перевести в категорию тяжких преступных деяний. Это оправданно, в частности тем, что нарушение правил дорожного движения в состоянии алкогольного опьянения, повлекшее по неосторожности смерть большого количества лиц, стоит на одной ступени (отражающей повышенный уровень общественной опасности) с тяжкими преступлениями. Помимо прочего, совершение таких деяний вызывает общественный резонанс. Что касается имеющихся в ныне действующей редакции четырех составов неосторожных тяжких преступлений (ч. 21, 4 ст. 263, ч. 4, 6 ст. 264 УК РФ), то в силу указанных выше замечаний, санкции за их совершение нуждаются в снижении пороговых границ и установлении максимума в пределах от пяти до десяти лет лишения свободы, при этом категория останется неизменной.

\section{Литература}

1. Иванчин А.В. Законодательная техника и ее роль в российском уголовном правотворчестве. М., 2011. 208 с.

\section{References}

1. Ivanchin A.V.Legislative technique and its role in Russian criminal law-making.M., $2011.208 p$

КУЛЕВА Людмила Олеговна, кандидат юридических наук, старший преподаватель кафедры уголовного права и криминологии Ярославского государственного университета им. П.Г. Демидова. 150003, г. Ярославль, Советская, 14. E-mail: ljudmila-pavlova11@rambler.ru

KULEVA Lyudmila Olegovna, Candidate of Law, Senior Lecturer, Department of Criminal Law and Criminology, Yaroslavl State University named after P.G.Demidov.150003, Yaroslavl, Sovetskaya, 14. E-mail: Ijudmilapavlova11@rambler.ru 